\title{
Vegetation communities in estuarine tidal flats in the different river and basin environments of the four major rivers of Ise Bay (Suzuka, Tanaka, Kushida and Miya), Mie Prefecture, Japan
}

\author{
Korehisa Kaneko $^{1^{*}}$, Seiich Nohara ${ }^{2}$ \\ ${ }^{1}$ Ecosystem Conservation Society-Japan, Tokyo, Japan; \\ *Corresponding Author: k kaneko@hotmail.com \\ ${ }^{2}$ Center for Environmental Biology and Ecosystem Studies, National Institute for Environmental Studies, Ibaraki, Japan
}

Received 10 January 2013; revised 13 February 2013; accepted 10 March 2013

Copyright (C) 2013 Korehisa Kaneko, Seiich Nohara. This is an open access article distributed under the Creative Commons Attribution License, which permits unrestricted use, distribution, and reproduction in any medium, provided the original work is properly cited.

\section{ABSTRACT}

In this study, we compared and analysed vegetation communities in the estuarine tidal flats of the four major rivers of Ise Bay (Suzuka River, Tanaka River, Kushida River and Miya River) in Mie Prefecture, Japan. Along the Suzuka River, Eragrostis curvula of the exotic plant accounted for $60.0 \%$ or more of the entire surface area, and the plant volume was high. Along the Tanaka River, Suaeda maritima community occupied the sand-mud zone in the vicinity of the shoreline on gravel bars, while Phragmites australis community was distributed along a shallow lake upstream. In the Kushida River, a salt marsh plant community (a community type found in areas flooded at high tide) of Suaeda maritima, Phragmites australis and Artemisia fukudo was distributed on the sand-mud surface along the main river. A salt marsh plant community (a community type found in areas that do not flood at high tide) of Phacelurus latifolius accounted for least $50.0 \%$ of the entire surface area. Along the Miya River, the area covered by the annual salt marsh plant community type was larger than the area occupied by this community type along the other rivers. The flow volume of the Miya River was high in April, June and August-October of 2006, July and September of 2007 and AprilJune of 2008. The flow volume was especially high in July 2007, when it reached levels above $1500.0 \mathrm{~m}^{3} / \mathrm{s}$; change in flow volume was also large. We suggest that a large-scale disturbance occurred in the estuary, resulting in the forma- tion of a gravelly sandy surface where an annual salt marsh plant community of Suaeda maritime and Artemisia fukudo has been established and grown as the annual precipitation and catchment volume of the basin have increased.

Keywords: Annual Salt Marsh Plant; Perennial Salt Marsh Plant; Flood Volume; Water Level;

Disturbance

\section{INTRODUCTION}

In Ise Bay, Mie Prefecture, Japan, shoreline conservation for the purpose of national land conservation has been proposed in the coastal areas. Instead securing the area, naturally occurring estuarine tidal flats have decreased in the area and left the shoreline vulnerable. After securing the area, the recovery of ecosystem diversity was included in the "reproduction action plan of Ise Bay" that was established in 2007 [1].

In the estuarine tidal flats of the four major rivers (Suzuka, Tanaka, Kushida and Miya) of Ise Bay, there are distinct vegetation types including salt marsh plant communities and exotic-upland plant communities [2]. Factors that influence the formation of vegetation types in the estuarine tidal flats include the ground level [3], differences between tidal-level and superficial sediments $[4,5]$ and ecosystem dynamics such as repeated disturbance and regeneration [6]. Additionally, the salt marsh plant communities found in low areas are influenced by the physical environment and sediment movement [710].

We aimed to determine whether the frequency of dis- 
turbance and the scale of change in flow volume and water level due to annual precipitation have greatly influenced the distribution of vegetation in the estuarine tidal flats. Given that there have been few previous studies addressing this problem, a detailed study would support the conservation and recovery of tidal flat environments.

In this study, we identified differences in vegetation communities and examined the relationship between vegetation communities and the environment (basin precipitation, water levels and flow volume) in the estuarine tidal flats of the four major rivers of Ise Bay.

\section{STUDY SITES AND METHODS}

\subsection{Study Site}

The study sites were located in the estuarine tidal flats of the four major rivers (Suzuka, Tanaka, Kushida and Miya) of Ise Bay, Mie Prefecture, Japan (Figure 1).

The study sites were selected from areas that experience the greatest influence from sediment deposition, both from upstream sediments and tide action. The river basin environments differ among the four rivers (Table 1). Suzuka River is a first-class river that is $38 \mathrm{~km}$ long with a basin area of $323 \mathrm{~km}^{2}$, and the mean annual precipitation in the basin for 1986-2005 was approximately $1800-2000 \mathrm{~mm}$ in the plains and exceeded $2200 \mathrm{~mm}$ in mountainous areas [11].

Data collection for Tanaka River included a verbal survey from the Tsu City office in the Mie Prefecture. Tanaka River is a second-class river that is $4.9 \mathrm{~km}$ long with a basin area of $8.5 \mathrm{~km}^{2}$, which includes Tsu City. The mean annual precipitation in the basin was approximately $1700-2300 \mathrm{~mm}$.

Kushida River is a first-class river that is $85 \mathrm{~km}$ long with a basin area of $461 \mathrm{~km}^{2}$. Mean annual precipitation in the basin for 1989-2008 was approximately 1600 $2200 \mathrm{~mm}$ in the middle and downstream basin and exceeded $2500 \mathrm{~mm}$ in mountainous areas [12].

Miya River is a first-class river that is $91 \mathrm{~km}$ long with a basin area of approximately $920 \mathrm{~km}^{2}$. Mean annual precipitation in the basin was greater than $2500-3000$ $\mathrm{mm}$ in the upstream basin and approximately 2000 $2500 \mathrm{~mm}$ in the middle and downstream basin [13].

\subsection{Vegetation Survey}

We used a survey of the study sites to map the distribution of plant communities $(1: 2500)$. Vegetation data were used to develop a physiognomic vegetation map with GIS (ArcView 3.1). For the plant community composition survey, we established transects to adequately sample all plant communities using the line transect method. Quadrants $\left(1 \mathrm{~m}^{2}\right)$ were established along the lines in each community, and cover and plant height were recorded for all species in each quadrant. In total, 84 quadrants were sampled (21 at each study site). All quadrants were marked with a pole and a flag.

\subsection{Statistical Methods}

\subsubsection{Classification of Vegetation Type}

The vegetation types were classified into 1) salt marsh plants and 2) exotic and upland plants (herbs). Salt marsh plants were defined as plants growing in the areas surrounding marshes and bogs near the mouth of the lagoon and the river in the coastal zone, and upland plants were classified as plants growing in locations of strong anthropogenic influence such as reclaimed areas [14] and

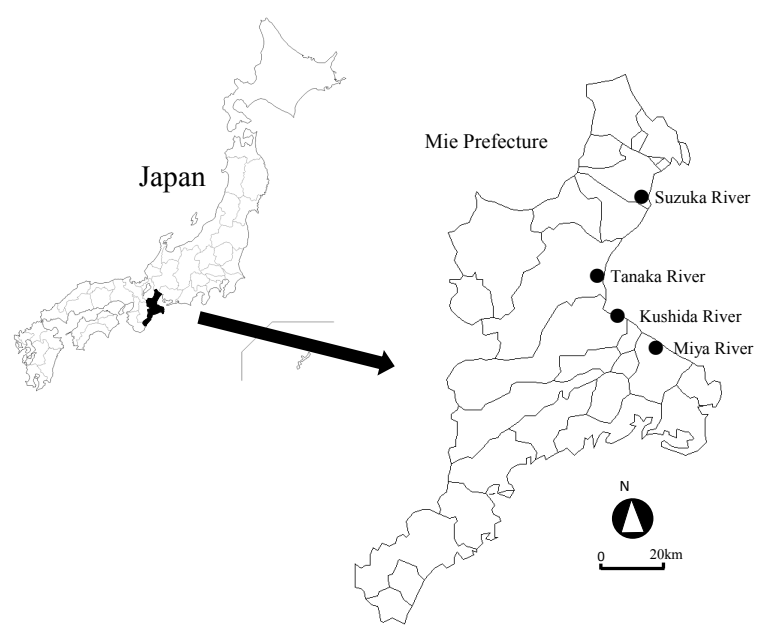

Figure 1. Location of the study sites.

Table 1. Total river length, basin area and mean annual precipitation for the four rivers.

\begin{tabular}{|c|c|c|c|c|}
\hline & Suzuka River & Tanaka River & Kushida River & Miya River \\
\hline Total length (km) & 38 & 4.9 & 85 & 91 \\
\hline Basin Area $\left(\mathrm{km}^{2}\right)$ & 323 & 8.5 & 461 & 920 \\
\hline \multirow{2}{*}{$\begin{array}{l}\text { Annual precipitation } \\
\qquad(\mathrm{mm})\end{array}$} & Mauntains area: about 2,200 mm & \multirow{2}{*}{$\begin{array}{c}1,700-2,300 \\
\mathrm{~mm}\end{array}$} & $\begin{array}{l}\text { Mauntains area: about } \\
2,500 \mathrm{~mm}\end{array}$ & Mauntains area: $2,500-3,000 \mathrm{~mm}$ \\
\hline & Plain area: $1,800-2,000 \mathrm{~mm}$ & & Plain area: $1,600-2,200 \mathrm{~mm}$ & Plain area: $2,000-2,500 \mathrm{~mm}$ \\
\hline
\end{tabular}

※ Annual precipitation of Tanaka River is indicated the average annual precipitation (1889-2010) of Tushi city. ※ In Tanaka River, water level is used the observation data of Mie Prefecture in Japan. 
in environments in which soil moisture is low [15]. Exotic plants were defined as plants brought in from foreign countries, and it is generally assumed that these plants were introduced after the Edo period in Japan [16].

\subsubsection{Plant Volume}

We calculated plant volume as follows:

Plant volume $=$ mean cover value $\times$ plant height $(\mathrm{m})$

$※$ The mean cover values were determined using the cover classes 1, 2, 3, 4 and 5, which were converted into $0.1 \%, 2.5 \%, 15 \%, 37.5 \%, 62.5 \%$ and $87.5 \%$, respectively, according to the Braun-Blanquet method [17].

\section{RESULTS}

\subsection{The Area and Proportional Area of Plant Community}

The area, proportional area and physiognomic vegetation map of each plant community are shown by studysite (Table 2, Figure 2). Along the Suzuka River, Eragrostis curvula, Carex kobomugi, Imperata cylindrical and Solidago canadensis communities were distributed on sand, while Phragmites australis and Suaeda maritima communities were distributed on sand and mud. However, the Eragrostis curvula community accounted for $60.0 \%$ or more of the entire surface area. The proportional area of salt marsh plant communities (a community type found in areas that flood at high tide) was low, with the Suaeda maritima and Phragmites australis communities each occupying $8.8 \%$ of the entire surface area. The proportional area of coastal plant communities was low, with an area of $5.3 \%$ for Carex kobomugi, $6.1 \%$ for Imperata cylindrical, $0.9 \%$ for Calystegia soldanella and $0.6 \%$ for Vitex rotundifolia.

Along the Tanaka River, the coastal plant communities were distributed on sandy high ground that does not typically flood at high tide. Suaeda maritima community was distributed in a zone of sand and mud in the vicinityof the shoreline on gravel bars, and Phragmites australis community was distributed in a muddy lake in the upstream portion of the river.

Along the Kushida River, Phacelurus latifolius and Hibiscus hamabo communities were distributed on sandy high ground that does not typically flood at high tide, while Suaeda maritima, Artemisia fukudo, Zoysia sinica and Phragmites australis communities were distributed on the low ground of sandy mud in the vicinity of the shoreline.

Along the Miya River, Suaeda maritime-Artemisia fukudo community and Phragmites australis community were distributed on sandy mud and gravelly sand in the vicinity of the shoreline, while Solidago canadensis and Eragrostis curvula communities were distributed on the sandy high ground. The salt marsh plant (annual and perennial) communities (community types that are found in areas that flood at high tide) were dominated by Suaeda maritime-Artemisia fukudo (41.1\%) and
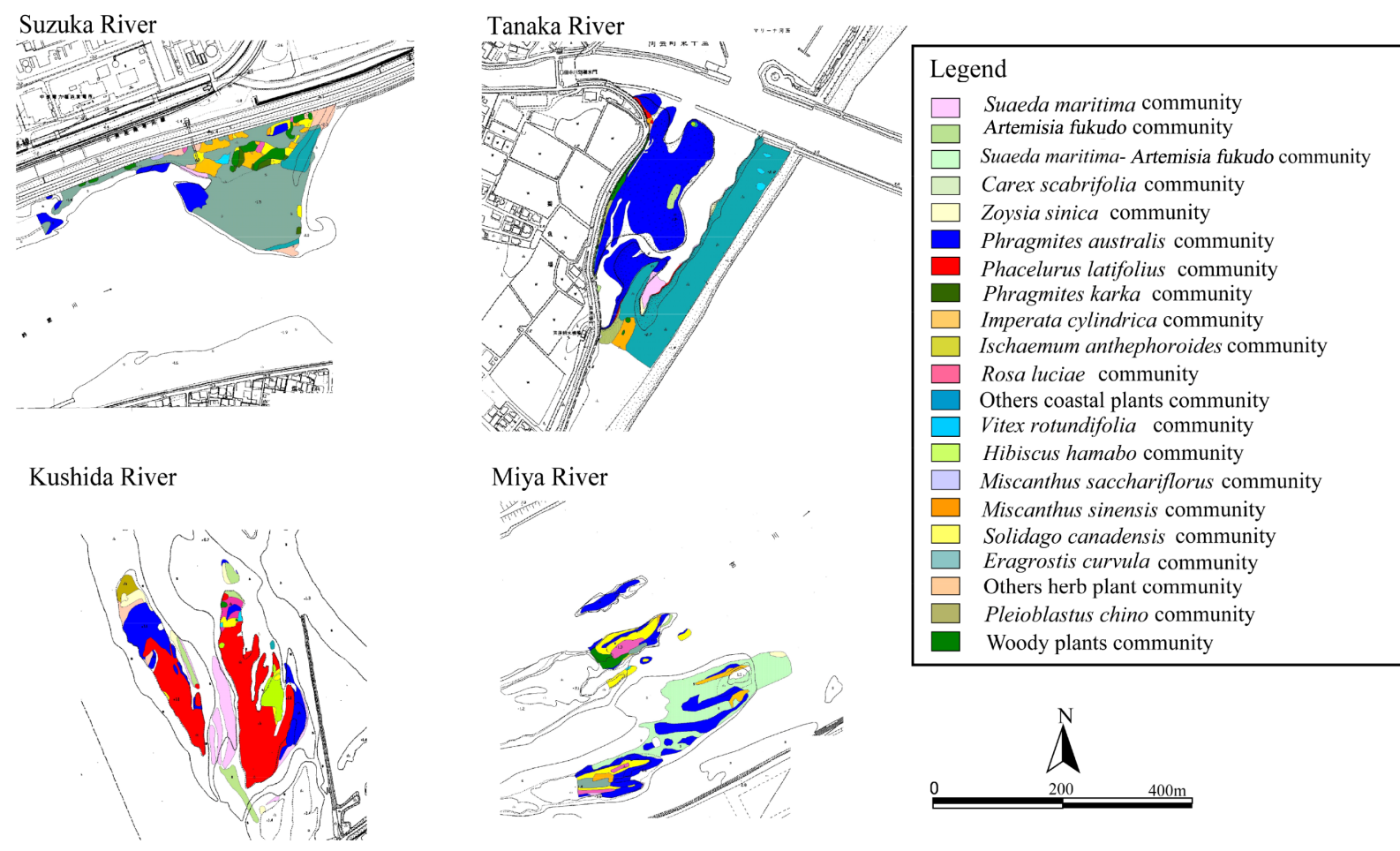

Figure 2. Physiognomic vegetation map of the estuarine tidal flats of 4 rivers in Ise Bay. 
Table 2. Area and proportional area of plant community types at the study sites.

\begin{tabular}{|c|c|c|c|c|c|c|c|c|c|}
\hline \multirow[b]{2}{*}{ Vegetation types } & \multirow[b]{2}{*}{ Plant community } & \multicolumn{2}{|c|}{ Suzuka River } & \multicolumn{2}{|c|}{ Tanaka River } & \multicolumn{2}{|c|}{ Kushida River } & \multicolumn{2}{|c|}{ Miya River } \\
\hline & & $\begin{array}{l}\text { Area } \\
\left(\mathrm{m}^{2}\right)\end{array}$ & $\begin{array}{l}\text { Proportional } \\
\text { Area }(\%)\end{array}$ & $\begin{array}{l}\text { Area } \\
\left(\mathrm{m}^{2}\right)\end{array}$ & $\begin{array}{c}\text { Proportional } \\
\text { Area }(\%)\end{array}$ & $\begin{array}{l}\text { Area } \\
\left(\mathrm{m}^{2}\right)\end{array}$ & $\begin{array}{l}\text { Proportional } \\
\text { Area }(\%)\end{array}$ & $\begin{array}{l}\text { Area } \\
\left(\mathrm{m}^{2}\right)\end{array}$ & $\begin{array}{l}\text { Proportional } \\
\text { Area }(\%)\end{array}$ \\
\hline \multirow{3}{*}{$\begin{array}{l}\text { Annual salt marsh plant } \\
\text { community } \\
\text { (flooding type at high tide) }\end{array}$} & Suaeda maritima community & 297 & 0.8 & 948 & 1.9 & 3,906 & 10.6 & 92 & 0.3 \\
\hline & $\begin{array}{c}\text { Suaeda maritima- } \\
\text { Artemisia fukudo community }\end{array}$ & - & - & - & - & - & - & 11,916 & 41.1 \\
\hline & Artemisia fukudo community & - & - & - & - & 2,726 & 7.4 & 92 & 0.3 \\
\hline \multirow{3}{*}{$\begin{array}{c}\text { Perennial salt marsh plant } \\
\text { community } \\
\text { (flooding type at high tide) }\end{array}$} & Carex scabrifolia community & - & - & 565 & 1.1 & - & - & - & - \\
\hline & Zoysia sinica community & - & - & 325 & 0.7 & 986 & 2.7 & 176 & 0.6 \\
\hline & Phragmites australis community & 2,903 & 8.0 & 22,486 & 45.2 & 6,113 & 16.6 & 9,091 & 31.4 \\
\hline \multirow{2}{*}{$\begin{array}{c}\text { Perennial salt marsh plant } \\
\text { community } \\
\text { (non-flooding type at high tide) } \\
\end{array}$} & Phragmites karka community & 678 & 1.9 & - & - & - & - & - & - \\
\hline & Phacelurus latifolius community & - & & 306 & 0.6 & 18,597 & 50.6 & - & - \\
\hline \multirow{9}{*}{ Coastal plant community } & Carex kobomugi community & 1,930 & 5.3 & - & - & - & - & - & - \\
\hline & Sonchus brachyotus community & - & - & 95 & 0.2 & - & - & - & - \\
\hline & $\begin{array}{l}\text { Ischaemum anthephoroides } \\
\text { community }\end{array}$ & - & - & - & - & 735 & 2.0 & - & - \\
\hline & Imperata cylindrica community & 2,210 & 6.1 & - & - & - & - & 854 & 2.9 \\
\hline & Calystegia soldanella community & 319 & 0.9 & 44 & 0.1 & - & - & - & - \\
\hline & Others costal plants community & - & - & 21,481 & 43.2 & 78 & 0.2 & - & - \\
\hline & Hibiscus hamabo community & - & - & 32 & 0.1 & 113 & 0.3 & - & - \\
\hline & Vitex rotundifolia community & 223 & 0.6 & 262 & 0.5 & 1,605 & 4.4 & 31 & 0.1 \\
\hline & Rosa luciae community & - & - & - & - & 630 & 1.7 & - & - \\
\hline \multirow{10}{*}{$\begin{array}{l}\text { Exotic-upland plant } \\
\text { community (herb) }\end{array}$} & $\begin{array}{l}\text { Miscanthus sacchariflorus } \\
\text { community }\end{array}$ & 114 & 0.3 & 50 & 0.1 & - & - & - & - \\
\hline & Miscanthus sinensis community & 176 & 0.5 & 968 & 1.9 & - & - & 302 & 1.0 \\
\hline & $\begin{array}{c}\text { Solidago canadensis } \\
\text { Miscanthus sinensis community }\end{array}$ & - & - & - & - & - & - & 529 & 1.8 \\
\hline & Solidago canadensis community & 1,214 & 3.3 & - & - & 539 & 1.5 & 2,999 & 10.3 \\
\hline & Eragrostis curvula community & 22,440 & 61.8 & - & - & - & - & 859 & 3.0 \\
\hline & Pueraria lobata community & - & - & 49 & 0.1 & - & - & - & - \\
\hline & Lolium multiflorum community & 342 & 0.9 & - & - & - & - & - & - \\
\hline & Sorghum halepense community & 508 & 1.4 & - & - & - & - & - & - \\
\hline & Xanthium occidentale community & 904 & 2.5 & - & - & - & - & - & - \\
\hline & Others herb plant community & - & - & 827 & 1.7 & 649 & 1.8 & 24 & 0.1 \\
\hline \multirow{4}{*}{$\begin{array}{l}\text { Exotic-upland plant } \\
\text { community (woody plant) }\end{array}$} & Rosa multiflora community & 229 & 0.6 & - & - & - & - & 1,185 & 4.1 \\
\hline & Pleioblastus chino community & - & - & 525 & 1.1 & - & - & - & - \\
\hline & Woody plants community & 1,824 & 5.0 & 769 & 1.5 & 91 & 0.2 & 830 & 2.9 \\
\hline & & 36,311 & 100 & 49,732 & 100 & 36,768 & 100 & 28,980 & 100 \\
\hline
\end{tabular}

※ The bold face is indicated the value that is the highest in the community.

Phragmites australis (31.4\%) and accounted for $70.0 \%$ or more of the entire surface area.

\subsection{Proportional Area and Distribution of Plant Community Types}

The proportional area of exotic plant communities (surface area of exotic plant community) was highest along the Suzuka River; perennial salt marsh plant communities (found in areas that flood at high tide) and coastal plant communities had the highest proportional area along the Tanaka River. The proportional area for perennial salt marsh plant communities (found in areas that do not typically flood at high tide) was highest along the Kushida River, and the proportional area of annual salt marsh plant communities was highest along the Miya River (Figures 3 and 4). 

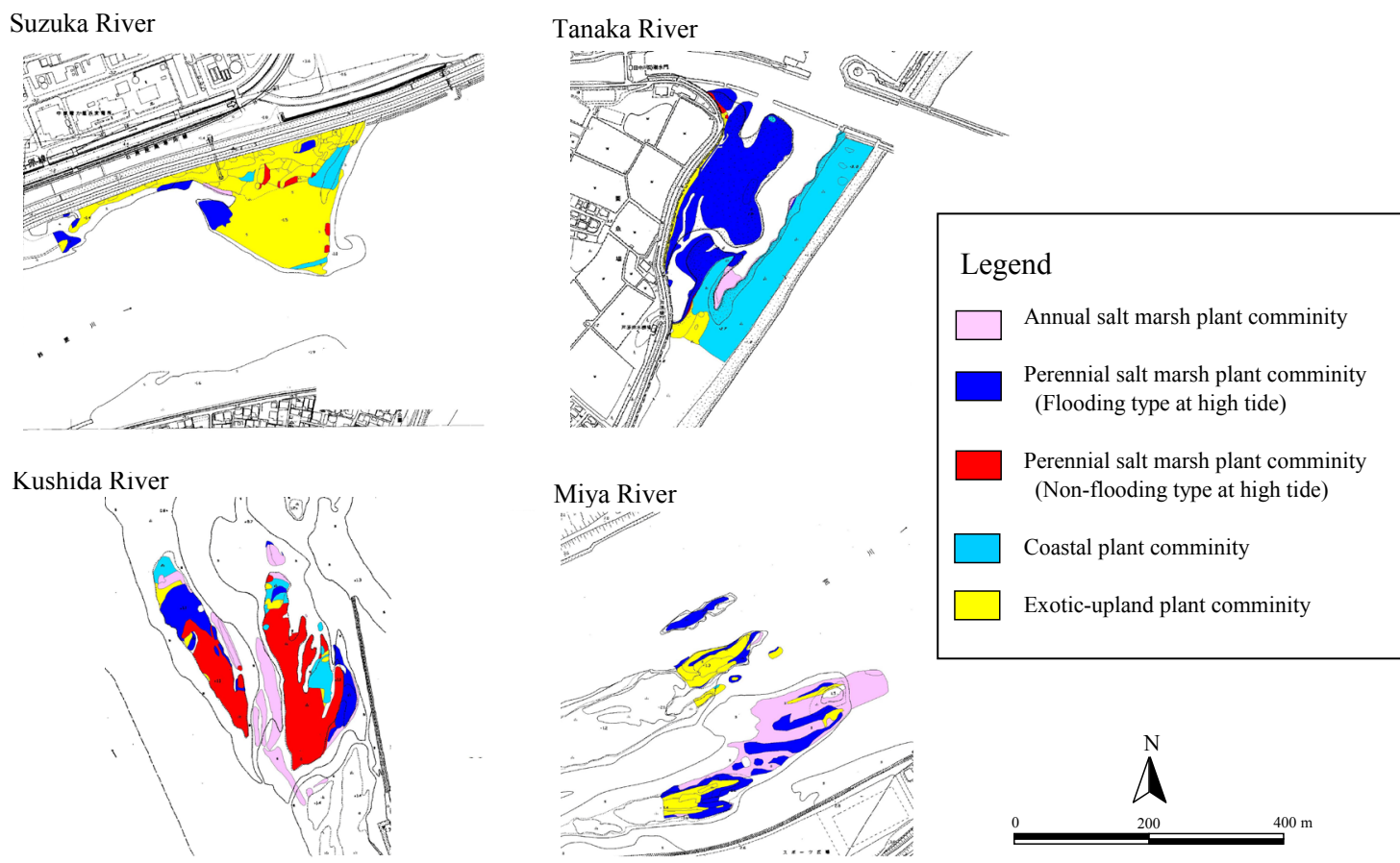

Figure 3. Distribution map of plant community types in the estuarine tidal flats of 4 rivers in Ise Bay.

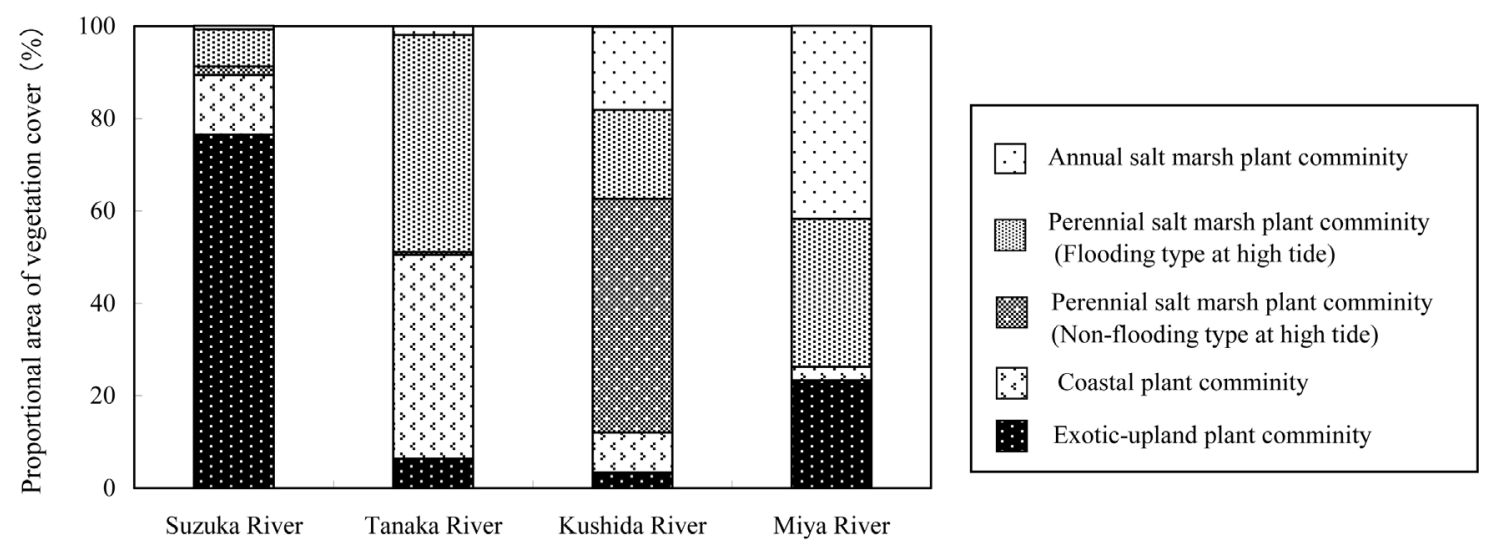

Figure 4. Proportional area of vegetation cover by plant community type at the study sites.

\subsection{Species Diversity}

The number of species per unit area for each plant type (flooded and non-flooded salt marsh plants, coastal plants and exotic-upland plants (herbs)) varied across the study sites. The number of species in the annual salt marsh plant (flooded) was relatively many along the Miya River and fewer along the Kushida, Tanaka and Suzuka rivers. Perennial salt marsh plant (flooded) had many species along the Miya River and fewer species along the Tanaka, Kushida and Suzuka rivers. Salt marsh plant (non-flooded) along the Kushida River had many species. Coastal plant had many species along the Tanaka River and fewer species along the Miya River. Exotic-upland plant had many species along the Suzuka River and a relatively fewer species along the Kushida,
Miya and Tanaka rivers (Figure 5).

\subsection{Plant Volume}

In comparing flooded or non-flooded salt marsh plants, coastal plants and exotic-upland plants at the study sites, the annual salt marsh plant (flooded) had the highest volume per area along the Miya River and lower volumes per area along the Kushida, Suzuka and Tanaka rivers. The perennial salt marsh plant (flooded) had the highest plant volume per area along the Miya River and a lower volume per area along the Tanaka, Kushida and Suzuka rivers. The salt marsh plant (non-flooded) had a higher volume per area along the Kushida River. The coastal plant had a high volume along the Kushida River and lower volumes along the Suzuka, Miya and Tanaka 
rivers. The exotic-upland had the highest volume per area along the Suzuka River and lower volumes along the Miya, Kushida and Tanaka rivers (Figure 6).

\subsection{Hydrological Environment at Each Study Site}

Flow volumes and water levels at each study site were examined using data for three-year period from January 2006 to June 2008 [18].

Regarding change in water level for each river, the water level in the Tanaka and Kushida rivers rose several times over the study period; however, these increases represented differences of less than $1.0 \mathrm{~m}$ from the minimum water levels for the rivers.

The water level in the Suzuka River rose to $1.0 \mathrm{~m}$ or more above the minimum water level during May-August of 2006, 2007 and May-June of 2008. Miya River showed frequently high levels except during winter and early spring. In particular, the water level in July 2007 reached a maximum that was approximately $4.0 \mathrm{~m}$ abovethe minimum water level (Figure 7). The change in water level was the largest in the Miya River (Figure 8).
Flow volume in the Miya River was highest in April, June and August-October of 2006, July and September of 2007 and April-June of 2008. Flow volumes in the Kushida and Suzuka Rivers were relatively low. In particular, the flow volume of the Miya River in July 2007 was extremely high, reaching over $1500.0 \mathrm{~m}^{3} / \mathrm{s}$. There are no data for the Tanaka River. Flow volume in the Miya River varied widely (Figure 7), and the largest change in flow volume occurred in the Miya River, relative to the other rivers (Figure 8).

\section{DISCUSSION}

\subsection{Differences in Vegetation among the Study Sites}

At the Suzuka River study sites, where sand was the major substrate, Eragrostis curvula of exotic plant was widely distributed and had highest plant volume (Table 2, Figures 2 and 3) Eragrostis curvula tolerates the movement of sand and water [19], and the accumulation of sand during high tides increases the amount of landsurface suitable for this species [20]. Additionally, Eragrostis curvula is used as a greening material in affore

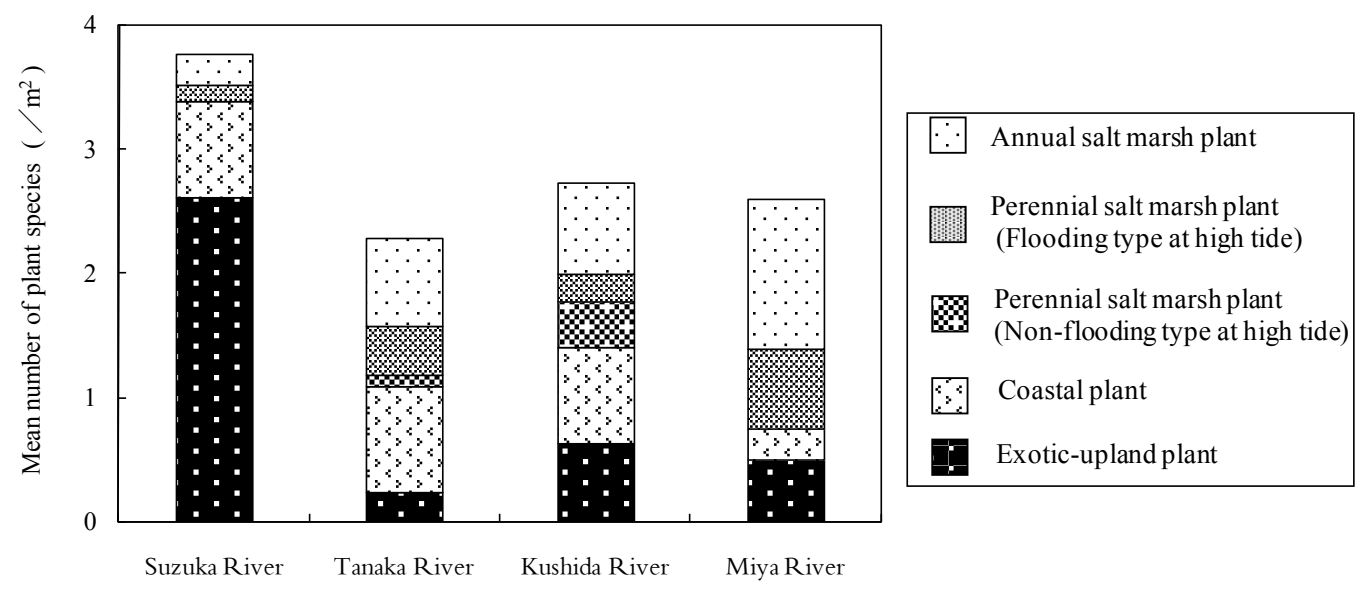

Figure 5. Mean number of plant species by plant community type at the study sites.

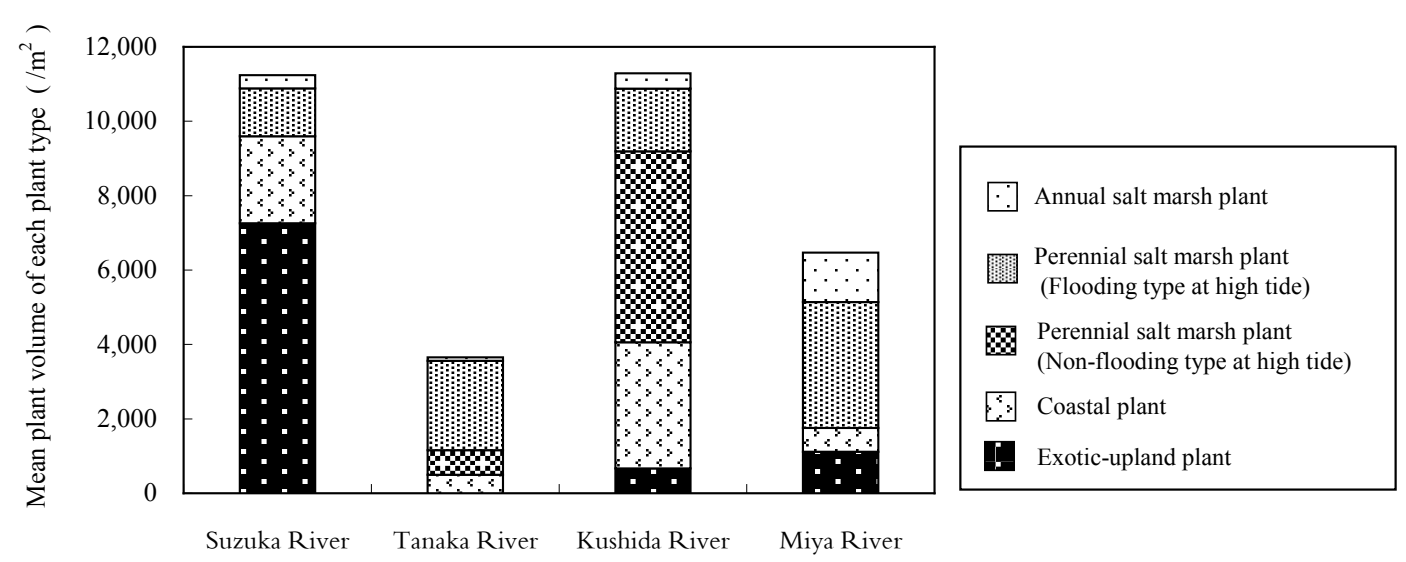

Figure 6. Mean plant volume by plant community type at the study sites. 

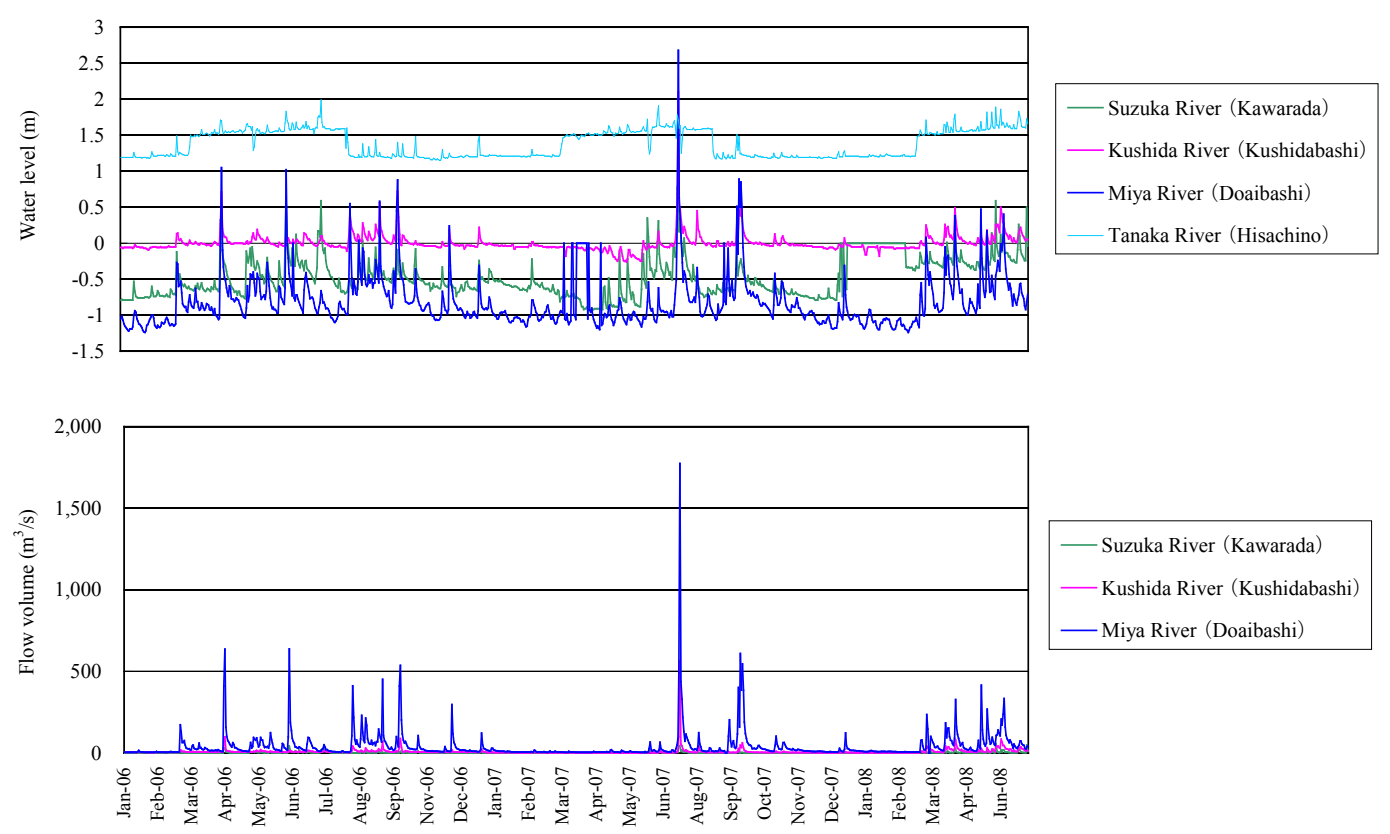

Figure 7. Changes in water level and flow volume for the four rivers (January 2006-June 2008). ※ For the Suzuka River, the Kushida River and the Miya River, data were obtained from the water information system of the Ministry of Land, Infrastructure, Transport and Tourism in Japan. ※ For the Tanaka River, water levels were determined using observation data from Mie Prefecture, Japan; however, there were no data for flow volume.
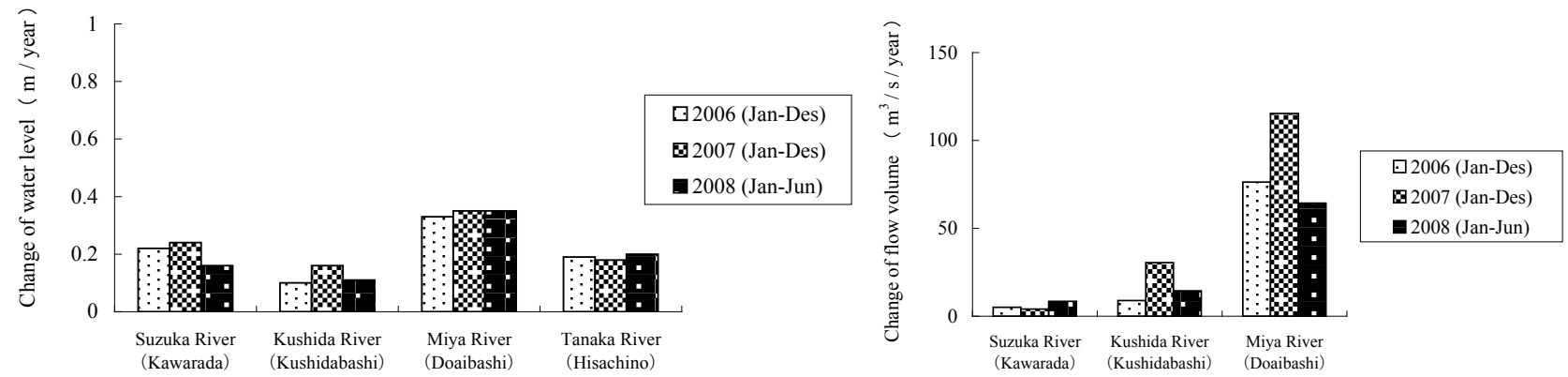

Figure 8. Changes in water level and flow volume per year (2006, 2007 and January-June 2008) for each river. $※$ Change values indicate the standard deviation. $※$ ( ) The location of data collection for the river. $※$ For the Tanaka River, water level data were obtained from Mie Prefecture, Japan; however, there were no data for flow volume. For 2008, data for depth and flow volume are limited to the period from January-June because the study was conducted in July 2008.

station and soil erosion control projects [21].

We suggest that along the Suzuka River, there was a low frequency of disturbance and a comparatively stable alluvial environment because the flow volume was extremely low compared to the Kushida and Miya rivers. However, the water level rose in June 2008 and during June-August of 2006 and 2007. We suggest that sediment accumulated in the estuary when the river rose to high water levels, forming high ground that was not flooded at high tide. The seeds of Eragrostis curvula growing in the vicinity germinated and were established on the new surface through water dispersal and anemochory. [22] reported that this type of vegetation is stable when tidal levels remain constant. We suggest that once high ground had formed in the estuarine tidal flats, the high surfaces were not easily flooded and the lack of flood disturbance allowed for the establishment of Eragrostis curvula.

In the estuarine tidal flats of the Tanaka River, Phragmites australis community, which is the perennial salt marsh (flooded) community type, occupied half of the surface area, while Suaeda maritime community which is the annual salt marsh plant community type was limited to sandy mud surfaces in the lagoon (Figure 2). The seeds of Suaeda maritime are dispersed by stream and other water movement, such as tides [23], and sometimes form seed banks [24]. The basin of the Tanaka River was extremely narrow compared to that of the other study sites, and the annual precipitation was relatively low 
(Table 1).

We suggest that the catchment volume of the river and the disturbance frequency are low, limiting the growth and distribution of annual salt marsh plant community type such as Suaeda maritime community. In contrast to salt marsh plants, the seed of Phragmites australis is dispersed by the wind and can occupy new sandy surfaces once established. Dense vegetation cover forms through vegetative propagation by a vigorous underground stem system, excluding many other species [25]. Additionally, Phragmites australis is relatively tolerant of high soil salinity and grows in dense communities in the brackish waters of estuaries [26]. We suggest that sediments from upstream were deposited beyond the overflow embankment during flood events, forming surface deposits by sand sprays. Phragmites australis germinated and grew on these deposits, expanding its cover by spreading rhizomes.

In the estuarine tidal flats of the Kushida River, marsh plant communities of Suaeda maritime, Phragmites australis and Artemisia fukudo (flooded type) were distributed on sandy mud surfaces along the main river channel. Salt marsh plant (non-flooded) communities as Phacelurus latifolius, coastal plant communities and exotic-upland communities were distributed on sandy, slightly higher ground (Figure 2). The proportional area of Phacelurus latifolius was greater than 50\% (Table 2). The flow volume of the Kushida River was the highest and reached a volume greater than $500.0 \mathrm{~m}^{3} / \mathrm{s}$ in July 2007 (Figure 7). Phacelurus latifolius was distributed on surfaces that do not flood at high tide, and this species is an indicator species to the upland area. Due to the low level of disturbance, fine sand accumulated in nonflooded areas and the areas transformed into high ground [27].

We suggest that the basin area of Kushida River is smaller than that of Miya River, and $50.0 \%$ or more of the entire surface area in Kushida River is occupied by upland which is non-flooded areas at high tide. However, disturbances occurred when flow volume increased due to heavy rain, forming new gravelly surfaces on which the annual salt marsh plants of Suaeda maritime and Artemisia fukudo germinated and grew, forming a new community.

In the estuarine tidal flats of the Miya River, where gravelly sand surfaces are predominant, the proportional area of annual salt marsh plant communities was the highest among the study sites (Figure 4). The flow volume of the Miya River reached more than $500.0 \mathrm{~m}^{3} / \mathrm{s}$ in April, July and October of 2006 and July and September of 2007. The flow volume of the Miya River was higher than that of the other study sites. The flow volume in July 2007 was extremely high, more than $1500.0 \mathrm{~m}^{3} / \mathrm{s}$ (Figure 7), and the change in flow volume was large
(Figure 8). Because the basin area of the Miya River was the largest among the study areas, the amount of annual rainfall was also the highest. We suggest that large-scale disturbances occurred in the estuary and formed the gravelly sandy deposits when flow volume reached more than $500.0 \mathrm{~m}^{3} / \mathrm{s}$ and water level rose to $1.0 \mathrm{~m}$ or more above the minimum water level. The annual salt marsh plants of Suaeda maritime and Artemisia fukudo germinated and grew as the annual precipitation and the catchment volume of the basin increased.

Based on our findings, we suggest that the scale and frequency of disturbance due to differences in basin area and annual precipitation greatly influence the vegetation in estuarine tidal flats.

\section{REFERENCES}

[1] Nishihara, T. (1997) As for recent movement of "Reproduction project of sea in Japan"-The action plan was settled on in the Ise Bay and the Hiroshima bay. Japanese Journal of Coastal Zone Studies, 19, 3-5.

[2] Mie Prefecture, Environmental Conservation Agency (2005) Threatened wildlife of Mie 2005. Plants Mushroom, Mie Prefecture, Japan.

[3] Kaneko, K., Yabe, T. and Nohara, S. (2005) Vegetation changes and topographic feature in the delta of Obitsu River in Tokyo Bay. Japanese Journal of Landscape Ecology, 9, 27-32.

[4] Kobayashi, S. (1996) The state environment of salt marsh plant community in the estuary-river course characteristics and salinity concentration environment. Research Report of Ehime Prefectural Science Museum JAPAN, 1, 35-44.

[5] Kamata, M. and Ogura, Y. (2006) Habitat evaluation for plant communities as a salt marsh in the Naka River, Shikoku. Ecology and Civil Engineering Society (Japan), 8, 245- 261. doi:10.3825/ece.8.245

[6] Kikuchi, E. and Kurihara, Y. (1988) Tide river. In: Kurihara, Y., Ed., Estuarine and Coastal Area of Ecology and Eco-Technology, Tokai University Press, Tokyo, 150-160.

[7] Delaune, R., Patrick, W. and Buresh, R. (1978) Sedimentation rates determined by $137 \mathrm{Cs}$ dating in a rapidly accreting salt marsh. Nature, 275, 532-533. doi: $10.1038 / 275532 \mathrm{a} 0$

[8] Deleeuw, J., Demunck, W., Olff, H. and Bakker, J. (1993) Does zonation reflect the succession of salt marsh vegetation? A comparison of an estuarine and a coastal island marsh in the Netherlands. Acta Botanica Neerlandica, 42, 435-445.

[9] Dijkema, K.S. (1997) The influence of salt marsh vegetation on sedimentation. In: Eisma, D., Ed., Intertidal Deposits River Mouths, Tidal Flats and Coastal Lagoons, CRC Press, Boca Ration, 403-414.

[10] Hatton, R.S., Delaune, R.D. and Patrick, W.H.J. (1983) Sedimentation, accretion, and subsidence in marshes of Barataria Basin, Louisiana. Limnology and Oceanogra- 
phy, 28, 494-502. doi:10.4319/10.1983.28.3.0494

[11] River Bureau of Ministry of Land, Infrastructure, Transport and Tourism. (2008) Outline of basin and river in Suzuka River water system (Plan). Ministry of Land, Infrastructure, Transport and Tourism, Tokyo.

[12] Mie Office of Rivers and National Highways of Ministry of Land, Chubu Region Maintenance Bureau, Infrastructure, Transport and Tourism (2010) Outline of basin in Kushida River. Ministry of Land, Infrastructure, Transport and Tourism, Tokyo.

[13] River Bureau of Ministry of Land, Infrastructure, Transport and Tourism (2007) Outline of basin and river in Miya River water system (Plan). Ministry of Land, Infrastructure, Transport and Tourism, Tokyo.

[14] Miyawaki, A., Okuda, S. and Suzuki, N. (1975) Vegetation in der umgebung der bucht von Tokyo. Institution for Transport Policy Studies, Tokyo.

[15] Kusanagi, T. (1986) Diagnosis of primary color weed. Rural Culture Association, Tokyo.

[16] Shimizu, T. (2003) Naturalized plants of Japan. HEIBONSHA, Tokyo.

[17] Braun-Blanquet, J. (1964) Pflanzensoziologie. SpringerVerlag, Wien. doi:10.1007/978-3-7091-8110-2

[18] Water Information System in Ministry of Land, Infrastructure, Transport and Tourism, Japan. http://www1.river.go.jp/

[19] Nakatubo, T. (1997) Established and the influence of Poaceae exotic herbs in river flood field. Japanese Journal of Conservation Ecology, 2, 179-187.
[20] Muranaka, T. and Washitani, I. (2001) Invasion of alien grass Eragrostis curvula on the gravelly floodplains of the Kinu River and decrease of river endemics: Necessity of urgent measures. Japanese Journal of Conservation ecology, 6, 111-122.

[21] Japanese Society of Turfgrass Science. (1988) New revision lawn and greening. Soft Science, Inc., Tokyo.

[22] Scott, Warren. R. and William, A. Niering. (1993) Vegetation change on a northeast tidal marsh: Interaction of sea-level rise and marsh accretion, Ecology, 74, 96-103. doi:10.2307/1939504

[23] Huiskes, A.H.L., Koutstaal, B.P., Herman, P.M.J., Beeftink, W.G., Markusse, M.M. and Munck, W.D.E. (1995) Seed dispersal of halophytes in tidal salt marshes. Journal of Ecology, 83, 559-567. doi:10.2307/2261624

[24] Hutchings, M.J. and Russel, P.J. (1989) The seed regeneration dynamics of an emergent salt marsh. Journal of Ecology, 77, 615-637. doi:10.2307/2260974

[25] Kira, T. (1991) Ecology of reed memorandum future article explore the way of the conservation of the waterside. Lake Biwa Research Center Report, 9, 29-37.

[26] Takada, H. (1974) Salt and biological: Basis of marine organism development. Sogensha, Osaka.

[27] Miyamoto, M. (2007) The effect of river channel-change on habitat and halophytes at Obitsu River estuary. Summary collection of master's thesis presentation in the 27th Annual Meeting of Kanto branch of the Ecological Society of Japan, 19. 